\title{
$\mathrm{ADH}$ 分泌異常症候群を伴った同時性重複肺癌の 1 例
}

\section{A Case of Double Primary Lung Cancer with SIADH}

杉山圭作・清水 健 -太田久彦・武田 潤 - 松岡 健

永田直一・高谷 治・中西邦昭*・河合俊明*

\begin{abstract}
要旨：75才, 男性. 胸部 $\mathrm{X}$ 線写真において右 $\mathrm{S}^{3}$ と左 $\mathrm{S}^{6} に$ 腫瘤㓌影を認め, 経気管支鏡的生検にて 右側は大細胞癌, 左側は小細胞癌, 燕麦細胞癌が確認された。また, 血液, 尿検查所見 より ADH分泌異常症候群 $(\mathrm{SIADH})$ を認めた。治療により左側腫瘤は著しく縮小したが, 右側は効果が少なく, 剖検では, 右S3に腺癌を認めた. SIADHを随伴した燕麦細胞癌と 同時性に腺癌を合併した例は稀と考之報告する。
\end{abstract}

〔肺癌 26(6)：707〜 712， 1986〕

Key words: Double primary lung cancer, SIADH.

\section{はじめに}

診断技術の向上とともに重複肺癌の症例は増 加しており，重契煙者で扁平上皮癌と扁平上皮 癌の組合せ，または扁平上皮癌と他の組織型の 癌の組合せの重複肺癌の例は, 比較的多く認め られるが，小細胞癌と腺癌の組合せの重複肺癌 の例は少なく，本邦では11例1) 7)のみである。今 回，我々は，燕麦細胞癌，他方が高分化腺癌で あり，両者間で治療効果が著しく異なっていて， 治療前の検査所見よりSIADHが認められた 1 例を経験した，治療経過中，燕麦細胞癌の消失 とともにSIADHが改善したことから, SIADH の原因となしうる燕麦細胞癌に腺癌を重複した 興味ある症例と考之, 報告する。

\section{症 例}

75才，男性。（B.I.1500）

主訴：咳嗽，血痰

既往歴：1982年，一過性脳虚血発作

防衛医科大学校第 3 内科

$*$ 同

第 1 病理
現病歴：1984年11月下旬，感冒様症状が出現 し，少量の血痰を認めるようになって，12月当 院を受診. 胸部X線写真 (Fig. 1 a,b) で異常㓌影 を認めたため入院となった.

入院時現症：左肺野で湿性ラ音を聴取した。 表在リンパ節の腫大はなく, その他の理学的所 見で異常を認めなかった。

入院時検查所見 (Table 1)：血沈の无進と血 清Naの低值の他には異常なく， $\alpha$ フェトプロ テインは正常範囲で, ツベルクリン反応は陽性. 喀痰においては，結核菌，塗抹・培養ともに陰 性. 肺機能検查は, 混合性障害を認めた。

胸部 X線所見 (Fig. 1 a, b) : 右 $\mathrm{S}^{3}$ に $3.4 \times 3.2$ $\mathrm{cm}$ の腫瘤院影があり, 側面像では左 $\mathrm{S}^{6}$ 末梢に境 界の一部が不鮮明な $3.5 \times 3.5 \mathrm{~cm}$ の円形㓌影を 認めた. 断層写真では左肺門りンパ節の腫脹が 疑われ，気管支透亮像で左主気管支の狭窄を認 めた。

気管支鏡所見：同日施行した気管支ファイバ 一スコープによって, 右側では可視範囲に所見 なく，左側では左主気管支の遠位側で粘膜血管 
Table 1. Laboratory data.

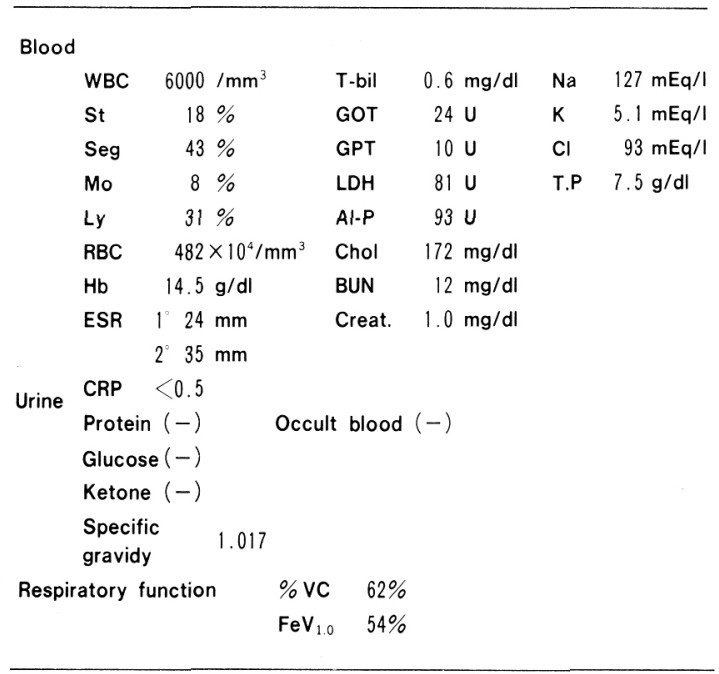

Fig. 1-a. December 24, 1984

Chest roentogenogram showing left hilar round shadow (arrowhead) and tumor shadow in right $\mathrm{S}^{3}$. (arrow)

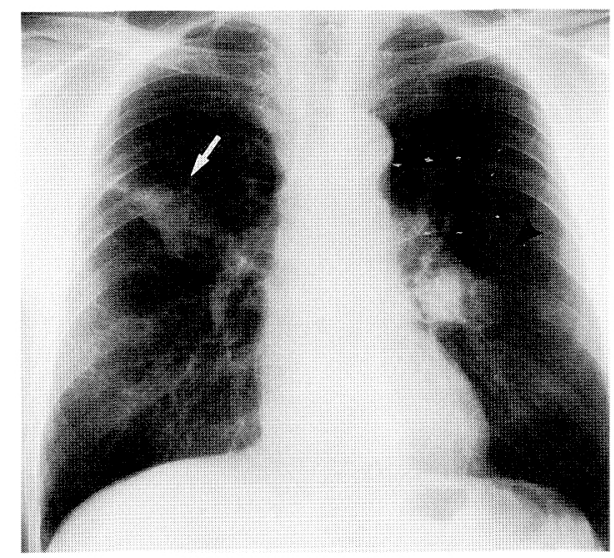

Fig. 1-b.

December 24, 1984

Lateral chest roentogenogram showing a round tumor shadow in the left $\mathrm{S}^{6}$ region. (arrow)

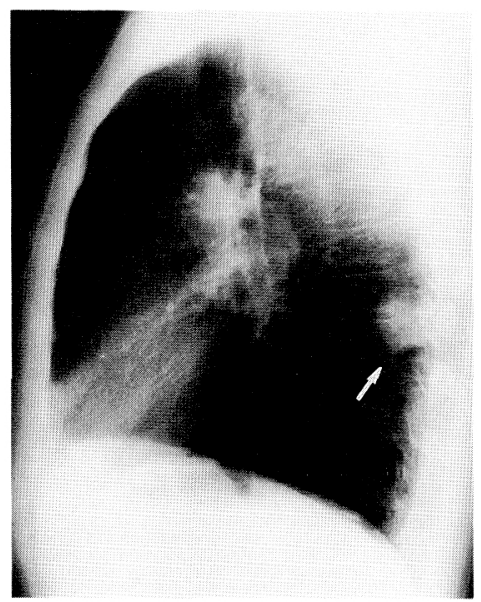

Fig. 2.

Biopsy specimen taken from the right lung tumor showing large cells without any differentiation.

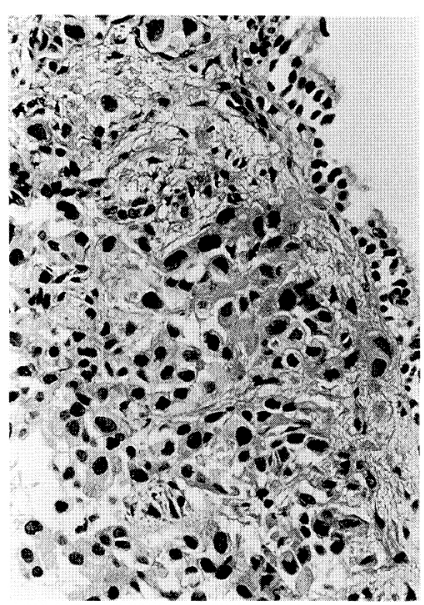

Fig. 3.

Biopsy specimen obtained from the left main bronchus showing slightly elongated and poorly cohesive cells with scarcely any cytoplasm. (Oat-cell carcinoma)
の軽度怒張を伴った腫瘍の浸潤と，外部よりの 圧迫のためと思われる著しい狭窄を認め, 同部 位より遠位側の観察は，全く行えなかった，膜 様部の呼吸性移動は，わずかであった。

経気管支肺生検組織所見：右側はTV透視下 で $\mathrm{S}^{3} b_{\mathrm{ii}}$ にて肺生検を施行し，気管支粘膜下に弱 好酸性の胞体をもち，充実性に増殖する大型の
腫瘍細胞を認めた。核は多形的で核小体は明瞭 でなかった。また明らかな腺管形成や粘液産生, 角化もなく，この時点での診断は大細胞癌とし た(Fig. 2)。一方, 左主気管支の生検では, 気管 支粘膜上皮下に, 小型のリンパ球類似の，胞体 の乏しい円形から紡錘型の腫瘍細胞の増殖が認 められ, 小細胞癌の燕麦細胞型と診断した( Fig. 
Table 2. Clinical Course.

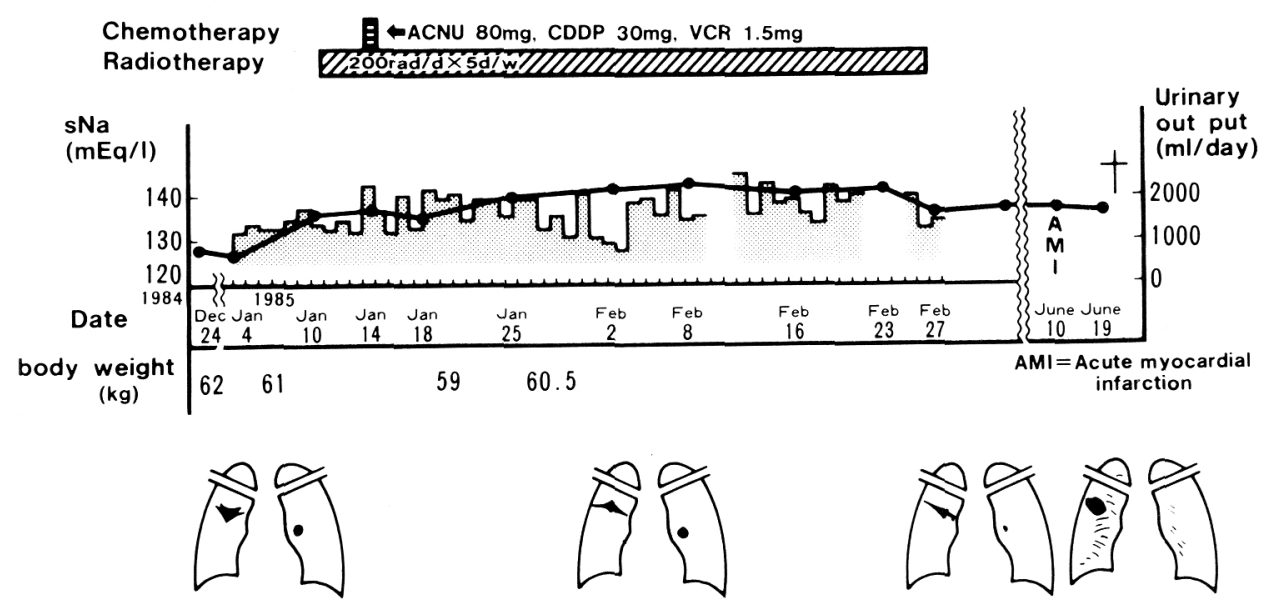

Fig. 4. February 2, 1985

Chest roentogenogram after chemotherapy showing remarkable reduction of left hilar shadow.

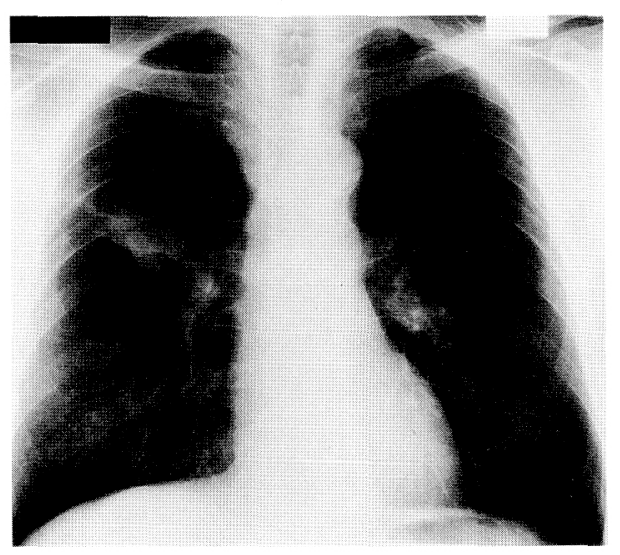

3）。なお，気管支鏡による生検を治療途中にお いてくり返し施行したが，両者の組織像とも初 回と等しい結果を認めた。

その他の所見：その他，骨髄穿刺， $\mathrm{Gaシンチ}$ グラム, 腹部のエコーCTスキャン, 頭部CTス キャンでは，いずれも転移を認めなかった。

入院後経過 (Table 2)：放射線治療は, ライナ ック照射を 1 回 $2 \mathrm{~Gy}$, 総量右側 $65 \mathrm{~Gy}$, 左側 $50 \mathrm{~Gy}$ まで，各病変に対し1985年 1 月11日より施行し た。化学療法は, ACNU 80mg, シスプラチン $30 \mathrm{mg}$ ，ビンクリスチン $1.5 \mathrm{mg}$ を同年 1 月 14 日よ
Table 3. Water-Na balance.

\section{Water-Na balance}

$\begin{array}{crrl} & 1985.1 .11 & 1.14 & \\ \text { sNa } & 136 & 136 & (\mathrm{mEq} / \mathrm{l}) \\ \text { Osm } & 274 & 271 & \left(\mathrm{mOsm} / \mathrm{kg} \cdot \mathrm{H}_{2} \mathrm{O}\right) \\ \text { ADH } & 7.8 & & (\mathrm{Pg} / \mathrm{ml}) \\ \mathrm{uNa} & 198 & 153 & (\mathrm{mEq} / \mathrm{l}) \\ \text { Osm } & 658 & 656 & \left(\mathrm{mOsm} / \mathrm{kg} \cdot \mathrm{H}_{2} \mathrm{O}\right)\end{array}$

\section{Other hormones}

$\begin{array}{lrlrl}\text { TSH } & 2.8 \mu \mathrm{U} / \mathrm{ml} & \mathrm{T}_{3} & 0.61 \mu \mathrm{g} / \mathrm{ml} \\ \text { T }_{4} & 7.6 \mu \mathrm{g} / \mathrm{ml} & & \\ \text { cortisol } & 17.6 \mu \mathrm{g} / \mathrm{ml} & \text { ACTH } & 28 \mu \mathrm{pg} / \mathrm{ml} \\ 17 \mathrm{KS} & 4.4 \mu \mathrm{g} / \mathrm{d} & 17-\text { OHCS } & 5.4 \mu \mathrm{g} / \mathrm{d} \\ \text { renin } & 2.1 \mu \mathrm{g} / \mathrm{ml} / \mathrm{h} & \text { aldosterone } & 140 \mu \mathrm{g} / \mathrm{ml}\end{array}$

り行なった。 2 月 2 日の胸部X線写真では，左 側の腫瘤㓌影は著しく縮小したが，右側は改善 の傾向を認奴かった(Fig. 4)。よって右側へ は，左側よりも放射線治療を $15 \mathrm{~Gy}$ 多く行なっ な.なお， 3 月 5 日施行した気管支鏡所見では， 左主気管支の狭窟は全く消失しており，主気管 支遠位側の粘膜にわずかに浮腫を認めたのみで あった。

入院時，低Na血症を認めたため，腫瘤の治療 前に，さらに精査を行ったところ，血清浸透圧 の低下，㽷の浸透圧の上昇, 尿中 $\mathrm{Na}$ 排泄の増加 
Fig. 5 Papillary adenocarcinoma cells proliferating with stromal connective tissue taken from the right $S^{3}$ in autopsy material.

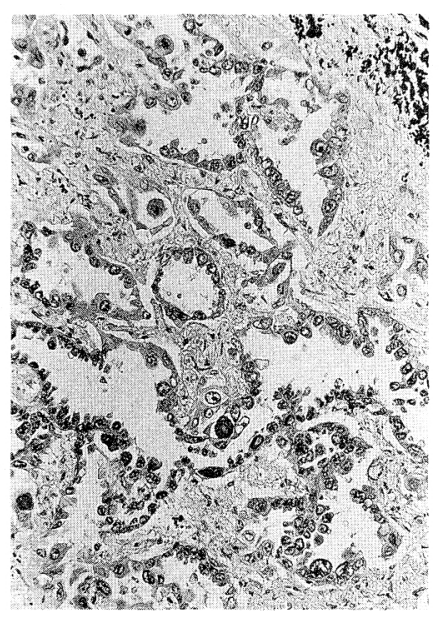

を認めたが, 同日の血中ADHは正常上限に維持 されていた(Table 3)。他の検查結果からは, 甲 状腺や副腎皮質機能の異常, その他による低 $\mathrm{Na}$ 血症は否定されたので, $\mathrm{ADH}$ 分泌異常症候群8) (SIADH) と診断して水制限を行なった。

以上のことに関連して, 入院時の生検で得ら れた左右肺の腫瘍組織を免疫組織化学的に検討 した. 使用した抗体はImmunotec S.A.社の抗バ ゾプレシン抗体である。コントロールの下垂体 後葉はADHで陽性に染色されたのに対し, 左右 肺いずれの腫瘍内にも ADHは陽性とはならな かった。しかし, 肺癌の治療により左側の腫瘤 が縮小した時点で水負荷試験を行なうと，4 時 間以内に負荷量の $90 \%$ 以上の尿量排泄之最大希 䣋時 $100 \mathrm{mOsm} / \mathrm{kg} \mathrm{H}_{2} \mathrm{O}$ 以下の尿浸透圧が得ら

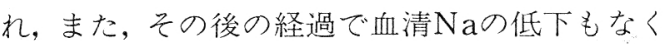
SIADHの病態は改善していた。

患者は1985年 6 月 19 日肺炎および心筋梗塞を 併発し, 全経過 7 カ月で死亡した。死亡直前の 胸部X線写真では, 右側の腫瘤陰影はやや増大 したが，左側の腫瘤は消失した。同時期の喀痰 細胞診では, 右肺の生検でみられた大細胞癌と 同様の細胞とともに，腺癌様細胞も認められた。

剖検所見：左肺には全く腫瘍細胞はなく, 右 肺では $S^{3} に$ 腫瘍を認めた。腫瘍は間質結合織を
伴い, 大小の腺管構造を有し, 最終的に高分化 の腺癌と診断した、肺癌の遠隔転移は, 燕麦細 胞癌, 高分化腺癌とも全く認めら扎なかった。

\section{考 察}

重複癌の定義は, Warren")らによると，(1)各 腫瘳が悪性腫瘍であること, (2)各々が明らかに 独立していること，(3)腫瘍は他から転移したも のではないこと，の 3 項目である。本症例にお いては, 胸部断層写真で左肺門リンパ節腫脹を 認めている。またintermediate typeの小細胞癌 が大細胞癌へと分化した例も報告されているの で10), 本症例の右肺癌の独立性については疑い ももたれたが，肺癌の一方が小細胞癌記麦細胞 型であり，他方は生検時，一部に扔いて大細胞 癌を思わせる未分化なところも存在したものの， 剖検で高分化腺癌を確認した。本症例では, 左 右で明らかに組織像が異なっており，しか㐘 tumor doubling timeは左肺腫瘤で13日, 右肺腫 瘤で85日と差を認め, 治療効果も著しく異なっ たことから，左右の肺癌はWarrenらの定義に あるように互いに独立したもので，重複癌と結 論した。

重複肺癌の報告は, 同時性のもの, あるいは 異時性のものがあるが，いずれの場合も扁平上 皮癌の関与するものが多い。本症例の上うに小 細胞癌と腺癌の重複した例は, 我々の調べ得た 範囲では, Bower ${ }^{11}$ らの組織像の異なった重複 肺癌255例中 12 例, 草地ら 1084 例中 4 例であっ た。この他, 本邦では 7 例報告されていた ${ }^{2) ~ 7) . ~}$ しかし, 橋本ら ${ }^{12)}$ の報告や米山ら ${ }^{13)}$ の報告では, 扁平上皮癌の関与する重複肺癌の組合せはそれ ぞれ 6 例ずつあるが，本例のような小細胞癌と 腺癌の組合せは，これらの報告のなかにはなく， ともに喫煙などの外的因子と非常に関係の深い 組織型の組合せの重複肺癌がより多く認められ ると考えられた。

SIADHに関しては, 今回は免疫組織化学的に 左肺の燕麦細胞癌, 右肺の腺癌, いずれの組織 内にもADHを見いだすことができなかったが， 左肺の燕麦細胞癌の腫瘤影の縮小とともに SIADHの病態が消失したため, ADHは燕麦細 
胞癌の方で産生されていた可能性が強いものと 考之られた。免疫組織化学的検査上でのADH㓌 性の理由は, 1) 生検組織が極小のためADH産生 のない部分しか得られない場合，2)生検材料を 固定する際に抗原性が失われた場合, 3)腫瘍の $\mathrm{ADH}$ の抗原性が通常の $\mathrm{ADH}$ と異なる場合，な どが考えられた、本例では, 臨床的にSIADHが 存在したことは確かで, 今後このような腫瘍随 伴症状のみられる重複癌では, 病態を詳しく調
べるためには，免疫組織化学的な検討を加えて いくことも必要と思われた。早川らの腺癌と 燕麦細胞癌の組合せの重複肺癌の例で, SIADH が認められており，本例と類似した点が多く興 味がもたれた。

以上, SIADHを伴った同時性重複癌と思われ る 1 例を呈示し, 若干の考察を加えた。

本症例は第82回日本肺癌学会関東部会で発表した.

\section{文 献}

1) 草地信也, 倉重真澄, 加藤 治, 他: 原発性肺 重複癌の 2 例一過去 10 年間の本邦報告例の集 計と検討一。日胸, $42: 419-425,1983$.

2）早川啓史, 岡野昌彦, 谷口正実, 他：組織型が 異なり同時発生した重複肺癌の 1 例. 肺癌, $25: 561,1985$.

3）森野英男, 横山朝夫, 細野芳美, 他 : 肺重複癌 の 1 剖検例. 肺癌, $19: 413,1979$.

4）富田正雄, 柴田紘一郎, 綾部公壹恣, 他: 多発性 原発肺癌。日胸，36：124-128，1977.

5）児玉 憲, 土井 修, 秋田信行, 他：皮膚筋炎 と間質性肺炎を合併した小細胞癌と腺癌の同 側同時性原発性重複肺癌の 1 手術例. 肺癌, $25: 85-92,1985$.

6）長井千輔, 小野田忠, 輿石匡司, 他：一期的切 除を行った画側性同時性重複肺癌の一例。肺 癌, $24: 785,1984$.

7）千保純一郎, 長谷川洋一, 佐々木忠, 他: 肺の 多重癌に関する検討。日胸疾会誌, $20: 238$, 1982.

8) Bartter, F.C. and Schwartz, W.B.: The syndrome of inappropriate secretion of antidiuretic hormone. Am. J.M., $42: 790-806$, 1967.

9) Warren, S. and Gates, O. : Multiple primary malignant tumors. A survey of the literature and statistical study. Am. J. Cancer, 16 : 1358-1414, 1932.

10) Zaharopoulos, P., Wong, J.Y. and Stewart, G. D. : Cytomorphology of the variants of small cell carcinoma of the lung. Acta Cytologica, $26: 800-808,1982$.

11) Bower, S.L., Choplin, R.H. and Muss, H.B. : Multiple primary bronchogenic carcinoma of the lung. Am. J. Radiol., 140 : 253-258, 1983.

12）橋本武志, 小林庸次, 古瀬清行, 他：原発性重 複肺癌一 1 剖検例の報告と重複癌についての 統計的観察一。癌の臨床, $22: 1370-1375$, 1976.

13）米山武志：臨床と病理との相関. 重複癌の臨床 病理, 国立ガンセンタ一編, 現代医科学大系. 臨床肺癌 IV，講談社，東京，199-208，1983. 


\title{
A Case of Double Primary Lung Cancer with SIADH
}

\author{
Keisaku Sugiyama*, Ken Shimizu*, Hisahiko Ota*, Jun Takeda* \\ Takeshi Matsuoka*, Naokazu Nagata*, Osamu Takatani* \\ Kuniaki Nakanishi** and Toshiaki Kawai ${ }^{* *}$ \\ *Third Department of Internal Medicine, National Defense Medical College, \\ Namiki 3-2, Tokorozawa, Saitama 359, Japan \\ **First Department of Pathology, National Defence Medical College
}

A case of double primary lung cancer was presented. Transbronchial lung biopsy revealed large cell carcinoma in the right lung and oat-cell (small cell) carcinoma in the left lung of a 75 yearold male. The left lung tumor was accompanied by syndrome of inappropriate secretion of $\mathrm{ADH}$ (SIADH). Radiotherapy and chemotherapy reduced the size of left lung tumor, and SIADH disappeared. Autopsy showed adenocarcinoma in the right lung. The incidence of double primary lung cancer, especially adenocarcinoma and small cell carcinoma, was discussed. 